\title{
Art Music by Caribbean Composers: U.S. Virgin Islands
}

\section{Christine Gangelhoff Cathleen LeGrand The College of The Bahamas ${ }^{1}$}

\section{INTRODUCTION}

Like so many other of the Caribbean islands discovered by Columbus, the U.S. Virgin Islands were settled by Spain. However, the Virgin Islands changed hands frequently and they were officially acquired by Denmark in the 17th century. The islands remained a Danish colony until purchased by the United States in 1917 ("Caribbean Islands," 2008). While the U.S. Virgin Islands consist of over 50 islands, its three major landforms are St. Croix, St. John and St. Thomas.

Virgin Island music is syncretic, reflecting both African and European heritage. While older traditions including cariso and bamboula are virtually extinct, quelbe is popular throughout the islands, with bands such as Stanley and The Ten Sleepless Nights performing frequently. "In 2003, the 25th Legislature of the Virgin Islands passed Bill No. 25-0056, which designates QUELBE as the official music of the Virgin Islands and requires that it be taught in the public schools" (Stanley, 2010).

Many music teachers receive their training at the University of the Virgin Islands (UVI), which offers a Bachelor degree in Music Education. UVI is also home to the Reichold Center for the Arts, one of the premier performance venues in the Caribbean, where performances of local and international artists are featured in an eclectic concert season.

The foremost composer native to the U.S. Virgin Islands is Alton A. Adams, Sr. Adams was the first black bandmaster of the United States Navy. "Adams's best-known compositions, Virgin Islands March (1919), The Governor's Own (1921), and Spirit of the U.S.N. (1924), were composed in the idiom of Adams's inspiration, Sousa, and were performed throughout the United States and

\footnotetext{
${ }^{1}$ Christine Gangelhoff, Assistant Professor, School of Communication and Creative Arts: Cathleen LeGrand, Public Services Librarian, Libraries and Instructional Media Services, The College of The Bahamas, P.O. Box N-4912, Nassau, Bahamas.

Cathleen LeGrand is now Librarian, at Royal Thimphu College, Ngabiphu, Thimphu, Bhutan.

Acknowledgments: The authors would like to thank the following for their contributions and assistance with this chapter: Alton Adams, Jr., Valrica Bryson, Bradley Christian, Dr. Lois Hassell-Habtes, Stanley Jacobs (and members of the Ten Sleepless Knights), Calvin Jones, Raymond La Motta, Dr. Ruby Simmonds, Beverly Smith, Neomie Toussaint-Williams, Dr. Leroy Trotman, Bertha C. Boschulte Middle School, Enid M. Baa Library Von Scholten Collection, St. Croix Educational Complex, and St. Croix Landmarks Society.

The authors are grateful to The College of The Bahamas for the grant that made this research possible. E-mail: cgangelhoff@cob.edu.bs How to cite this article in APA 7th ed. style: Gangelhoff, C., \& LeGrand, C. (2011). Art music by Caribbean composers: U.S. Virgin Islands. The International Journal of Bahamian Studies, 17(1), 53-59. https://jdoi.org/10.15362/ijbs.v17i1.131
} 
Europe by leading ensembles ...” (Adams, 2008, p. 8). His VIRGIN ISLANDS MARCH is considered the islands' official anthem. Although he employed the traditional form of the march in these works, he incorporated rhythms of quelbe, for example, in the trio section of the Virgin Islands March. In Adams's WARBLING IN THE MOONLIGHT, a work for piccolo with band accompaniment, he draws on the binary structure typically found in quelbe music.

Wilbur "Bill" La Motta is another major composer from the USVI. He wrote a variety

\section{REFERENCES}

Caribbean Islands: US Virgin Islands. (2008).

In Philip's world factbook, 2008-2009.

Retrieved from

http://www.credoreference.com/entry/philip

swfb/caribbean_islands_us_virgin_islands of vocal and instrumental works, often based on local traditional melodies. La Motta came from a musical family; his brother, Raymond, is also a composer. Like his brother, Raymond La Motta wrote compositions influenced by local culture and tradition. One such tradition is the DANZA, a dance form of Puerto Rican origin that has become a cultural standard in the U.S. Virgin Islands owing to the large number of Puerto Ricans living there and to the close ties between the two islands (R. La Motta, personal communication, May 2011).

Clague, M. (Ed.). (2008). The memoirs of Alton Augustus Adams Sr.: First black bandmaster of the United States Navy. Berkeley, CA: University of California Press.

Stanley \& the Ten Sleepless Nights: Performing quelbe music for 40 years. (2010, June 8). St. Croix Source. Retrieved from http://www.stcroixsource.com 


\section{COMPOSERS}

Alton Augustus Adams, Sr. (1889-1987)

Hugo Bornn (1902-1966)

Yvette Fleming Brandy

Cyril Creque (1899-1959)

Charles Henry Emanuel (1891-1979)

Raymond La Motta (1926-) ${ }^{2}$

Wilbur "Bill" La Motta (1919-1980)

Alfred Nemours (1876-1943)

Judith C. Peterson Rabsatt (1952-)

Gylchris Sprauve

Louis V. Trotman (1945-)

Lois Trotman-Simmonds (1946-)

Luis A. Wheatley (1916-)

COMPOSITIONS

Adams

Caribbean echoes (Valse tropicale)

Childhood merriment (waltz)

Doux rêve d'amour (1912; waltz)

Virgin Islands march (1917)

The Governor's own (1921; march)

Sincerity (waltz)

The spirit of the United States Navy (march)

Sweet Virgin Islands

Until

Warbling in the moonlight (for band with piccolo)

\section{Bornn}

Blossom (for chorus)

Day dream (for piano)

Moon revel (for piano)

${ }^{2}$ According to Raymond La Motta, "La Motta" is the preferred spelling (personal communication, May 2011)

\section{Brandy}

Virgin Islands Christmas (c.2005; for chorus) ${ }^{3}$

\section{Creque}

\section{Centennial song}

From mark of the yoke (1948)

The upward way (1959)

The virgins

\section{Emanuel}

Debonaire (march)

\section{La Motta, R.}

En mis Islas Virgenas (c.1984)

He blessed me simply (c.2011; for chorus \& piano)

\section{La Motta, W.}

Alma mater by the sea (alma mater for the University of the Virgin Islands)

Bolero for Don Pablo (aka Don Pablo's Bolero)

Calypso escapades (for piano)

Caribbean capriccioso (for piano)

La compassionata (for piano)

Dancing bougainvillaeas (for piano)

Dawn from a window in paradise

Fortitude (for piano)

Have you thanked the Lord (1973; for chorus \& piano)

The King's Point victory (marching song for U.S. Merchant Marine Academy)

The last bamboula

The melancholy seagull (for piano)

Moon rocturne (for piano)

${ }^{3}$ Commissioned by the Caribbean Chorale; premiered as part of a Caribbean Chorale concert held in late 2005 at Christchurch Methodist in Charlotte Amalie, St. Thomas, U.S. Virgin Islands. 
Nirvana's lullaby (for piano)

Prayer for the Virgin Islands (1973; for chorus \& piano)

St. John impressions (for piano)

Spirit of the Virgin Islands

The ultimate tranquility (for piano)

Valse dilettante (for piano)

Winds on a psychic sea

\section{Nemours}

Soiree de Berlin (waltz for piano)

Air de ballet (for piano)

Comtesse et Marquis

Tendre aveu, op. 8 (violin solo)

\section{Peterson Rabsatt}

Lord, make me an instrument (2007; for male voices \& piano) ${ }^{4}$

\section{Trotman}

O, merciful Father (1993) ${ }^{5}$

Except the Lord build the house (2000) ${ }^{6}$

My dwelling place (2007) ${ }^{7}$

\footnotetext{
${ }^{4}$ Commissioned for the New Herrnhut Moravian Men's Chorale in Celebration of the 270th Anniversary of the Oldest Moravian Church in the New World in St. Thomas, U.S. Virgin Islands. Adapted from the "Prayer for Peace" of St. Francis of Assisi

${ }^{5}$ Hymn written for the choir at the Church of St. Alban the Martyr (Episcopal) in Queens, NY.

${ }^{6}$ Commissioned for the New Herrnhut Moravian Men's Chorale, based on Psalm 127.

${ }^{7}$ Commissioned for the New Herrnhut Moravian Senior Choir in Celebration of the 270th Anniversary of the Oldest Moravian Church in the New World in St. Thomas, US Virgin Islands, based on Psalm 90.
}

\section{Trotman-Simmonds}

Come one, come all (1994) ${ }^{8}$

Create in me a clean heart, O God (1997; for mixed voices)

Love never faileth (for solo soprano voice)

Variation on a familiar hymn: "More love to thee" (arranged by Trotman-Simmonds) ${ }^{9}$

\section{SCORES}

\section{Bornn}

Bornn, H. (n.d.). Blossom. Available from http://www.sheetmusicplus.com.

\section{La Motta, W.}

La Motta, W. (1973). Have you thanked the Lord? St. Thomas, V.I.: Westindy Music.

La Motta, W. (1973). Prayer for the Virgin Islands. St. Thomas, V.I.: Westindy Music.

This far by faith: An African-American resource for worship. (1999). Minneapolis, MN: Augsburg Fortress. Available from http://www.augsburgfortress.org.

[Have you thanked the Lord]

\section{Peterson Rabsatt}

Peterson Rabsatt, J. C. (c.2007). Lord make me an instrument. St. Thomas, V.I.:

Posaunenberg.

\section{Trotman-Simmonds}

Trotman-Simmonds, L. (c.2007). Variation on a familiar hymn: "More love to thee." St. Thomas, V.I.: Posaunenberg Publishing Co.

\footnotetext{
${ }^{8}$ Commissioned for the New Herrnhut's Men's Chorale

${ }^{9}$ Words by W.H. Doane, Music by Elizabeth Prentiss. Commissioned for the New Herrnhut Moravian Senior Choir in Celebration of the 270th Anniversary of the Oldest Moravian Church in the New World in St. Thomas, US Virgin Islands
} 


\section{RECORDINGS}

\section{Adams}

Complete national anthems of the world, vol. 1 [CD]. (2005). Hong Kong: Marco Polo Naxos. (Marco Polo 8.225319; disc 1 of 4, 1:11:06)

Track 10. Virgin Islands march (2:34)

Track 11. Virgin Islands march (short version) (1:44)

Track 12. Virgin Islands march (Olympics version) (1:12)

The golden age of the American march [CD]. (1992). [Recorded by the Goldman Band; Richard Franko Goldman, conductor.] New York, NY: New World Records. (New World 80266; one disc)

Track 1. The Governor's own (2:26)

\section{SOUND FILES}

\section{Adams}

Available at

http://www.newworldrecords.org/album.cgi ?rm=view\&album_id=80266

[The Governor's own]

\section{WEBSITES}

Adams, Alton Augustus, Sr. (n.d.). Profiles of outstanding Virgin Islanders. Retrieved from http://www.stx.k12.vi/profiles/Adams.htm

Bornn, Hugo Owen. (n.d.). Profiles of outstanding Virgin Islanders. Retrieved from http://www.stx.k12.vi/profiles/Bornn.htm

Creque, Cyril Felix William. (n.d.). Profiles of outstanding Virgin Islanders. Retrieved from http://www.stx.k12.vi/profiles/Creque_C.htm
Emanuel, Charles Henry. (n.d.). Retrieved from

http://webpac.uvi.edu/imls/pi_uvi/profiles19

92/Educators/Emanuel_C/index.shtml

La Motta, Wilbur. (n.d.). Profiles of outstanding Virgin Islanders. Retrieved from

http://www.stx.k12.vi/Profiles/lamottaB.htm

Wheatley, Luis Andres. (n.d.). Profiles of outstanding Virgin Islanders. Retrieved from

http://www.stx.k12.vi/Profiles/Wheatley.htm

\section{BOOKS, ARTICLES AND THESES}

Clague, M. (2007). An American first: Alton

Augustus Adams: First black bandmaster of the U.S. Navy. Paper presented at the Conference of the College Band Directors National Association, Ann Arbor, MI. Retrieved from http://www.cbdna.org/conference2007/hand outs/adams.pdf

Clague, M. (1998). Instruments of identity: Alton Augustus Adams Sr., the Navy Band of the Virgin Islands, and the sounds of social change. Black Music Research Journal, 18(1/2), 21-65. doi:10.2307/779394

Clague, M. (Ed.). (2008). The memoirs of Alton Augustus Adams Sr.: First black bandmaster of the United States Navy. Berkeley, CA: University of California Press.

Daniel, Y. (2006). Come with me and let's talk about Caribbean quadrilles. Cariso, 6, 6-12. Retrieved from http://www.colum.edu/cbmr/PDF_folder/Ca riso2006issue6.pdf

Floyd, S. A. (1977). Alton Augustus Adams: The first black bandmaster in the U. S. Navy. The Black Perspective in Music, 5(2), 173-187. doi:10.2307/1214078 
Funeral booklet for Wilbur Lamotta. (1980).

Retrieved from Digital Library of the

Caribbean website:

http://ufdc.ufl.edu/CA01300228/00001

Hassell-Habtes, L. (2006). More than a bandmaster: The life and times of Alton Augustus Adams, Sr., a cultural odyssey. Cariso, 6, 1-3. Retrieved from http://www.colum.edu/cbmr/PDF_folder/Ca riso2006issue6.pdf

Horne, A. (1996). Brass music of black composers: A bibliography. Westport, CT: Greenwood Publishing. Available at Google Books.

[pp. 13-14: Alton A. Adams; p. 195: W. La Motta]

Jarvis, J. A. (1944). The Virgin Islands and their people. Philadelphia, PA: Dorrance.

[pp. 162-65 includes coverage of VI music and information on A. Nemours]

Kienberger, K. P. (2005, Winter). Teaching the music of Alton Adams. Cariso, 9-10.

Retrieved from http://www.colum.edu/cbmr/PDF_folder/Ca riso2005winter.pdf

La Motta, W. (1967). Music of a people. In Fifty years: Commemorating the fiftieth anniversary of the transfer of the Virgin Islands from Denmark to the United States of America (p. 25). St. Thomas, V.I.: St. Thomas Friends of Denmark Society.

Lekis, L. (1960). Virgin Islands (Chapter 13). In Dancing gods (pp.176-186). New York, NY: Scarecrow Press.

Lieth-Philipp, M. (2010). Alton A(ugustus)

Adams. Grove Music Online. Oxford, England: Oxford University Press.

Lieth-Philipp, M. (2010). Bill [Wilbur] La Motta. Grove Music Online. Oxford, England: Oxford University Press.
Lincoln, S. (2001, November 28). Adams Institute to be center of music research. St. Croix Source. Retrieved from http://stcroixsource.com/content/artsentertainment/showcase/2001/11/28/adamsinstitute-be-center-music-research

Simmonds, R. (1995). The words beneath the sand: An examination of the works of three Virgin Islands poets. (Unpublished doctoral dissertation). Clark Atlanta University.

[Ch.3: "The nature of Cyril Creque's romanticism," pp. 44-93]

Simmonds-Esannanson, R. (2003, Summer). Another sound of the V.I. voice: The music of Cyril F.W. Creque. Cariso, 1-6. Retrieved from:

http://www.colum.edu/cbmr/PDF_folder/Ca riso2003summer.pdf

St. Thomas-born composer presents score of Virgin Islands Christmas to AMRI. (2006). Cariso, 5, 3. Retrieved from http://www.colum.edu/cbmr/PDF_folder/Ca riso2006issue5.pdf

Thomas, D. (2005). Alton Augustus Adams: One of the best-known musicians of the U.S. Virgin Islands. Journal of Band Research, 41(1), 30-41.

\section{LIBRARIES}

Alton Augustus Adams papers.

The Center for Black Music Research (CBMR).

Library \& Archives, Columbia College, 618 South Michigan Avenue, 6th Floor Chicago, IL 60605

Telephone: (312) 369-7586

Finding aid available at http://www.colum.edu/cbmr/PDF_folder/Fin ding\%20Aids/CBMR_Alton_Adams.pdf 
Alton Augustus Adams clippings file.

New York Public Library

Performing Arts Research Collections

Music Division.

40 Lincoln Center Plaza

New York, NY 10023-7498

Telephone: (917) 275-6975

Cyril Creque papers.

The Center for Black Music Research (CBMR). Columbia College, Chicago, IL. Library \& Archives:

618 South Michigan Avenue, 6th Floor

Chicago, IL 60605

Telephone: (312) 369-7586
Dominique-René de Lerma papers.

The Center for Black Music Research

(CBMR). Columbia College, Chicago, IL.

Finding aid available at http://www.colum.edu/CBMR/PDF_folder/F inding\%20Aids/CBMR_de_Lerma.pdf

[Alton A. Adams; W. La Motta]

Von Scholten collection.

Enid M. Baa Public Library \& Archives. \#20 Dronningens Gade

St. Thomas, V.I. 00802

Telephone: (340) 774-0630

St. Croix Landmarks Society

Library and Archives

52 Estate Whim, Frederiksted

St. Croix, Virgin Islands, 00840

Telephone: (340) 772-0598

Library catalogue available at http://www.stcroixlandmarks.com/ 